\title{
Utilizing Green Glass Cullet, Local Ball Clay and White Clay For Producing Light Greenish Brown Color Wall Tile
}

\author{
Ubolrat Wangrakdiskul $^{1}$,Witsanu Loetchantharangkun ${ }^{2}$ \\ ${ }^{1}$ Production Engineering Department, Faculty of Engineering, King Mongkut's University \\ of Technology North Bangkok, Thailand \\ ${ }^{2}$ Production Engineering Department, Faculty of Engineering, King Mongkut's University \\ of Technology North Bangkok, Thailand
}

\section{ARTICLE INFO \\ Keywords: \\ Local clay utilization, Eco-friendly wall tile, Green glass cullet}

\begin{abstract}
This paper aimed to develop eco-friendly wall tiles from green color waste glass and local clay in Thailand. Owing to containing high fluxing agent, green glass cullet had been selected to develop wall tiles. It can reduce the sintering temperature of ceramic bodies. In addition, the green color of waste glass can promote the new texture of ceramic wall tiles. All materials used in this study consisted of green glass cullet (GGC), local ball clay (LBC), and local white clay (LWC). They were dried, milled, and sieved through a 50 mesh (297 micrometers) screen. Mixture formulations of materials had been conducted by using a tri-axial diagram. The rectangular specimens with dimension 50x100x 7 $\mathrm{mm}$ were prepared by uniaxial pressing. They were all fired at $950 \mathrm{oC}$ with soaking for $1 \mathrm{~h}$. Bending strength and water absorption of specimens were tested and compared with a Thai Industrial Standard (TIS 2508-2555). The results revealed that the formula contained $60 \% \mathrm{GGC}, 30 \% \mathrm{LBC}$, and $10 \% \mathrm{LWC}$ can achieve TIS 2508-2555. In addition, Scanning Electron Microscopy and X-Ray Diffraction technique were employed to characterize the microstructure of specimens. This can be summarized that utilizing waste glass and combining with local clay can develop eco-friendly fired clay wall tiles with light greenish brown texture.
\end{abstract}

\section{Introduction}

According to the policy of Thai government, it had been conducted for supporting the development of SMEs to achieve sustained and healthy economic growth [1]. This research was also performed for complying with this policy. Therefore, development of new products for saving energy and creating new texture product was proposed to the community ceramic

\footnotetext{
$\square$ Corresponding Author E-Mail Address: ubolrat_w@hotmail.com
} 
plant in Angthong province of Thailand. Consecutively, environmental problem of waste disposal is also the important concern. From the yearly report by the pollution control department in 2016 [2], 42\% of waste glass in Thailand is not utilized, amounting to $1,014,653$ tons.

There are many works studied about utilizing waste glass for manufacture of white ware ceramic bodies [3]. Youssef et al, had suggested the utilizing soda lime glass in wall and floor tiles which were fired at $1100^{\circ} \mathrm{C}$ [4]. In 2005, substitution waste glass in feldspar for making porcelain was proposed. It can reduce sintering temperature and make cheaper cost of material [5]. Braganca et al, had utilized sand from foundry industry, clay, and waste glass for producing white ware ceramics fired at $1100^{\circ}, 1300^{\circ} \mathrm{C}$. It can meet properties of Brazilian standards [6].

Roofing tiles with red color were produced at $750^{\circ} \mathrm{C}$ by mixing reddish yellow kaolinite clay and waste glass varying ratio from 0 to $15 \%$ [7]. Waste glass (WG) had been studied by substituting in feldspar $(\mathrm{F})$ for producing porcelain stoneware tiles. The proportional of 5 $\mathrm{WG}$ and $25 \mathrm{~F}$ used fired range between $1000^{\circ}-1250^{\circ} \mathrm{C}$ were suggested [8].

In addition to studying white ware ceramic bodies, valorizing waste glass for fire clay bricks was also proposed by many researchers. Effect of waste glass on properties and durability of fired clay bricks had been investigated. The study suggested the proportion of fine and coarse particle size of waste glass and firing temperature at $1035^{\circ} \mathrm{C}$ [9]. Incorporation of waste glass in fired clay bricks can enhance their physical and mechanical properties [10,11, 12, and 13].

Furthermore, local clays had been recognized for developing ceramic bodies as well. Thailand is one of countries in Asia having many resources i.e. kaolin clay, ball clay, and white clay, which can be utilized for producing ceramic products. White clay and ball clay, which are available in Prachinburi province [14], had been employed to combine with waste glass.

As reviewed researches mentioned above, substitution waste glass as fluxing agent for manufacturing low sintering fired clay wall tile was the objectives of this study. The expected results of this study was to create the light greenish brown color eco-friendly wall tile.

\section{Materials and Methods}

\subsection{Materials}

Three main materials used in this study consisted of GGC, LBC, and LWC. Their compositions were analyzed by X-ray fluorescence (XRF) method as shown in Tab 1. GGC played a role as reducing sintering temperature and promoting green color of ceramic tiles. Due to having plasticity, LBC and LWC were utilized for facilitating specimens' preparation. In addition, containing $\mathrm{Fe}_{2} \mathrm{O}_{3}$ in local clay can promote brown color in fired ceramic bodies. Tri-axial diagram was employed for formulation mixtures of the experiment. The six groups consisting of 33 formulas are conducted as shown in Tab 2. They are classified by varying \% GGC quantities for each group. 
Table 1: Chemical composition of materials used in this study by XRF technique

\begin{tabular}{|c|c|c|c|c|c|c|c|c|c|c|c|c|c|c|c|c|c|}
\hline \multicolumn{2}{|c|}{ Compound } & $\mathrm{SiO}$ & $\mathrm{Al} \bigcirc$ & $\mathrm{FeO}$ & $\mathrm{K} O$ & $\mathrm{CaO}$ & $\mathrm{MgO}$ & $\mathrm{TiO}$ & $\mathrm{MnO}$ & $\mathrm{P} O$ & $\mathrm{NaO}$ & SO & $\mathrm{BaO}$ & $\mathrm{Rb} \odot$ & $\mathrm{ZnO}$ & $\mathrm{ZrO}$ & $\mathrm{Cr} O \mathrm{O}$ \\
\hline \multirow{3}{*}{$\begin{array}{c}\text { Concentration } \\
(\%)\end{array}$} & GGC & 69.9 & 1.91 & 0.43 & 0.36 & 10.8 & 1.24 & 0.08 & & & 14.6 & 0.07 & 0.09 & & 0.03 & 0.03 & 0.3 \\
\hline & LBC & 66.7 & 24.7 & 3.89 & 1.85 & 0.09 & 0.94 & 0.86 & 0.02 & 0.09 & 0.2 & 0.55 & 0.07 & 0.01 & 0.01 & 0.03 & 0.01 \\
\hline & LWC & 58.4 & $\begin{array}{l}37.9 \\
\end{array}$ & 2.11 & 0.19 & 0.04 & 0.13 & 1.06 & & 0.06 & & 0.09 & & & & 0.06 & 0.01 \\
\hline
\end{tabular}

Remark: GGC = Green Glass Cullet, LBC = Local Ball Clay, LWC = Local White Clay

Table 2: Formulation mixtures of the experiment

\begin{tabular}{|c|c|c|c|c|c|c|c|c|c|c|c|c|c|c|c|c|c|c|c|c|c|c|c|c|c|c|c|c|c|c|c|c|c|}
\hline \multirow{2}{*}{\multicolumn{2}{|c|}{ Group No. }} & & \multicolumn{7}{|c|}{$\mathbf{D}$} & \multicolumn{6}{|c|}{ C } & & \multicolumn{4}{|c|}{ E } & \multicolumn{3}{|c|}{$F$} \\
\hline & & - & & & & & & & & & 0 & $E$ & & $m$. & & $n$ & & $\Xi$ & $\infty$ & 9 & & $\overrightarrow{\mathrm{v}}$ & $\begin{array}{ll}4 \\
\text { N }\end{array}$ & $\vec{a}$ & \begin{tabular}{c|c}
9 \\
9
\end{tabular} & $\begin{array}{lll}n & 0 \\
v & 0\end{array}$ & & \begin{tabular}{l|l}
$\hat{\alpha}$ & $\infty$ \\
$N$
\end{tabular} & $\begin{array}{ll}0 & \hat{v}\end{array}$ & i & $\bar{m}$ & $\begin{array}{ll}N \\
m\end{array}$ & $m$ \\
\hline \multirow{3}{*}{ Composition } & & 10 & 10 & 10 & 10 & 10 & 0 & 10 & 10 & 20 & 20 & 20 & 20 & 202 & 0 & 20 & 30 & 30 & 30 & $\begin{array}{lll}30 & 3\end{array}$ & $\begin{array}{lll}30 & 3\end{array}$ & 30 & 40 & 40 & \begin{tabular}{l|l}
40 & 4
\end{tabular} & $40 \quad 40$ & 105 & \begin{tabular}{l|l}
50 & 50
\end{tabular} & \begin{tabular}{l|l}
0 & 50
\end{tabular} & 50 & 60 & 60 & 60 \\
\hline & LBC & 10 & 20 & 30 & 40 & 50 & 00 & 70 & 00 & 10 & 20 & 30 & 40 & 50 & & 70 & 10 & 20 & 30 & $40 \mid 5$ & $\begin{array}{lll}50 & 6\end{array}$ & 60 & 10 & 20 & \begin{tabular}{l|l|l}
30 & 4
\end{tabular} & \begin{tabular}{l|l}
40 & 50
\end{tabular} & 5010 & \begin{tabular}{l|l|l}
10 & 20
\end{tabular} & $\begin{array}{lll}0 & 30\end{array}$ & 40 & 10 & 20. & 30 \\
\hline & LWC & 80 & 70 & 60 & 50 & 40 & 30 & 20 & 10 & 70 & 60 & 50 & 403 & 30 & 20 & 10 & 60 & 50 & 403 & 302 & 201 & 10 & 50 & 40 & 302 & 2011 & \begin{tabular}{l|l}
0 & 4 \\
\end{tabular} & 1030 & $\begin{array}{lll}0 & 20 \\
\end{array}$ & 10 & 30 & 20 & 10 \\
\hline
\end{tabular}

\subsection{Methods}

All mixture formulas were dried by electric oven and milled by pot mill in a lab scale to produce fine particles. They were sieved under 50 mesh (297 micrometer). Mixture of formulas were pressed by uniaxial pressing at 100 bar to form rectangular specimens of dimension $50 \times 100 \times 7 \mathrm{~mm}$. Sintering temperature of specimens was set up at $950^{\circ} \mathrm{C}$ with $100^{\circ} \mathrm{C} / \mathrm{h}$ and soaked for $1 \mathrm{~h}$ at maximum temperature. Then, fired specimens were tested the physical and mechanical properties which will be described as follows.

Bending strength of specimens was evaluated by three point bending using the equation of $3 \mathrm{PL} / \mathrm{bd}^{2}$, where $\mathrm{P}$ is the load (force) at the fracture point $(\mathrm{N}), \mathrm{L}$ is the length of the support span $=80 \mathrm{~mm}, \mathrm{~b}$ is width, and $\mathrm{d}$ is thickness of sample. Water absorption was determined by immerging the samples into water and boiling water with samples for $2 \mathrm{~h}$ and leaving them under water for $24 \mathrm{~h}$. Then calculating a difference of dry and wet weight of specimens dividing by their dry weight. Bending strength and water absorption of test samples were carried out and compared with Thai Industrial Standard 2508-2555 (TIS 2508-2555). Linear shrinkage of fired specimen was determined by measuring the length before and after firing and dividing by its length before firing. Weight loss of fired specimens was evaluated. Weight loss of fired clay body was determined by measurement difference of its dry weight and fire weight body divided by its dry weight. Furthermore, bulk density of specimens was carried out by Archimedes technique.

In addition to testing physical and mechanical properties, microstructure of specimens was also investigated. X-ray Diffraction (XRD) pattern was carried out for analyzing the crystal phase of fired specimens. The phases occurred in the fired clay bodies were determined with X-ray diffraction (XRD), conducted on a Bruker D8 Advance diffractometer. The scanning electron microscopic (SEM) pattern was performed by Hitachi series SU3500 to analyze the crystal structure and porosity of specimen. The prepared samples were coated with the gold layer before testing. Results of test samples will be described in the following section. 


\section{Results and discussion}

\subsection{Mechanical and physical properties}

As analyzing the composition of each material used (Tab 1), fluxing agent contents which lower the sintering temperature of ceramic bodies [12] are calculated. Comparison of fluxing agent in each formula with bending strength, linear shrinkage, weight loss is conducted (Tab $3)$. It shows that increasing fluxing agent content $(\mathrm{Na} 2 \mathrm{O}, \mathrm{K} 2 \mathrm{O}$, and $\mathrm{CaO})$ has increased bending strength, linear shrinkage and weight loss. This can be summarized that effect of fluxing agent can enhance bending strength. Because they act as sintering aid for lower the sintering point of specimens. The highest strength value is $18.51 \mathrm{MPa}$ of formula no. F33 having the highest fluxing agent. Linear shrinkage is also increased according to increasing of fluxing agent. Owing to having high carbonaceous matter [15], LBC (Local Ball Clay) has an effect on weight loss of fired specimens. Therefore, the highest content of LBC (formula no. A8) leads to high of weight loss.

Higher content of GGC makes lower density of specimens in group F (See Tab 4). However, bulk density of all formulas is slightly different, varying from 2.22 to 2.53 . The value of water absorption of formula no. F33 having $60 \%$ wt. of GGC is the lowest value. In addition to enhance bending strength, fluxing agent in GGC leads to reduced porosity. Moreover, influence of LWC which having $\mathrm{Al}_{2} \mathrm{O}_{3}$ content higher than that of the others makes the high water absorption of specimens (formula no. A1). 
Table 3: Composition, fluxing agent, bending strength, linear shrinkage, weight loss of 33 formulas

\begin{tabular}{|c|c|c|c|c|c|c|c|c|}
\hline \multirow[b]{2}{*}{ Gap } & \multirow[b]{2}{*}{$\mathbf{N b}$} & \multicolumn{3}{|c|}{ Composition } & \multicolumn{4}{|c|}{ Pysicd and Medharical Poperties } \\
\hline & & COG & LBC & LUC & $\%$ fluxing & $\begin{array}{l}\text { Bending } \\
\text { S(MPa) }\end{array}$ & $\begin{array}{c}\% \\
\text { Srinkage }\end{array}$ & $\begin{array}{l}\% / \mathrm{dt} \\
\text { Loss }\end{array}$ \\
\hline \multirow{8}{*}{ A } & $\mathbf{A}$ & 10 & 10 & 80 & 298 & 1.37 & 0.99 & 7.41 \\
\hline & A & 10 & 20 & 70 & 3.17 & 1.38 & 1.02 & 7.74 \\
\hline & $\bar{A}$ & 10 & 30 & $\mathbf{6 0}$ & 336 & 204 & 1.06 & 884 \\
\hline & A & 10 & 40 & 50 & 3.55 & 261 & 1.14 & 887 \\
\hline & A6 & 10 & 50 & 40 & 3.74 & 334 & 1.16 & 9.41 \\
\hline & A6 & 10 & 60 & 30 & 3.93 & 481 & 1.26 & 10.74 \\
\hline & $\boldsymbol{A}$ & 10 & 70 & 20 & 413 & 655 & 1.34 & 11.66 \\
\hline & A8 & 10 & 80 & 10 & 432 & 856 & 1.58 & 14.64 \\
\hline \multirow{7}{*}{ B } & B & 20 & 10 & 70 & 554 & 220 & 1.19 & 646 \\
\hline & B10 & 20 & 20 & $\mathbf{6 0}$ & 573 & 331 & 1.22 & 660 \\
\hline & B11 & 20 & 30 & 50 & 592 & 358 & 1.27 & 684 \\
\hline & $\mathrm{Bl2}$ & 20 & 40 & 40 & 6.11 & 406 & 1.29 & 694 \\
\hline & B13 & 20 & 50 & 30 & 630 & 671 & 1.54 & 7.12 \\
\hline & B14 & 20 & $\mathbf{6 0}$ & 20 & 649 & 7.16 & 1.61 & 7.30 \\
\hline & B15 & 20 & 70 & 10 & 668 & 843 & 1.68 & 887 \\
\hline \multirow{6}{*}{ C } & $\mathbf{C 6}$ & 30 & 10 & 60 & 810 & 454 & 1.54 & 556 \\
\hline & C7 & 30 & 20 & 50 & 829 & 493 & 1.69 & 560 \\
\hline & C18 & 30 & 30 & 40 & 848 & 631 & 1.72 & 577 \\
\hline & C19 & 30 & 40 & 30 & 867 & 657 & 1.74 & 589 \\
\hline & $\mathrm{CO}$ & 30 & 50 & 20 & 886 & 7.67 & 1.79 & 611 \\
\hline & C21 & 30 & $\mathbf{6 0}$ & 10 & 9.05 & 9.86 & 210 & 856 \\
\hline \multirow{5}{*}{ D } & $\mathbf{D 2}$ & 40 & 10 & 50 & 10.65 & 636 & 1.79 & 532 \\
\hline & $\overline{\mathbf{D Z}}$ & 40 & 20 & 40 & 10.84 & 7.95 & 215 & 551 \\
\hline & $\overline{D 24}$ & 40 & 30 & 30 & 11.04 & 843 & 217 & 577 \\
\hline & D25 & 40 & 40 & 20 & 11.23 & 868 & 236 & 626 \\
\hline & D26 & 40 & 50 & 10 & 11.42 & 10.13 & 239 & 7.86 \\
\hline \multirow{4}{*}{$E$} & E27 & 50 & 10 & 40 & 13.21 & 7.ळ3 & 230 & 4.33 \\
\hline & $E 8$ & 50 & 20 & 30 & 13.40 & 822 & 233 & 441 \\
\hline & $\mathrm{E2}$ & 50 & 30 & 20 & 13.59 & $\overline{10.63}$ & 235 & 478 \\
\hline & E0 & 50 & 40 & 10 & 13.78 & 11.40 & 237 & 497 \\
\hline \multirow{3}{*}{$F$} & F31 & 60 & 10 & 30 & 1577 & 16.57 & 259 & 417 \\
\hline & $\mathrm{F} 2$ & 60 & 20 & 20 & 15.96 & 16.97 & 260 & 441 \\
\hline & $\mathrm{F33}$ & $\mathbf{6 0}$ & 30 & 10 & 1615 & 1851 & 261 & 481 \\
\hline
\end{tabular}

Remark: Specimens contain $>60 \%$ GGC unable to be performed

Table 4: Composition, bulk density, and water absorption of 33 formulas

\begin{tabular}{|c|c|c|c|c|c|c|}
\hline \multirow[b]{2}{*}{ Group } & \multicolumn{3}{|c|}{ Composition } & \multicolumn{3}{|c|}{ Physical Properties } \\
\hline & No. & GCG & LBC & LWC & $\begin{array}{r}\text { density } \\
(\mathrm{g} / \mathrm{cc})\end{array}$ & \%absorption \\
\hline \multirow{8}{*}{ A } & $\mathrm{A} 1$ & 10 & 10 & 80 & 2.47 & 21.56 \\
\hline & $\mathrm{A} 2$ & 10 & 20 & 70 & 2.48 & 21.25 \\
\hline & A3 & 10 & 30 & 60 & 2.49 & 20.62 \\
\hline & A4 & 10 & 40 & 50 & 2.51 & 20.02 \\
\hline & A5 & 10 & 50 & 40 & 2.51 & 19.07 \\
\hline & A6 & 10 & 60 & 30 & 2.51 & 19.04 \\
\hline & A7 & 10 & 70 & 20 & 2.52 & 18.60 \\
\hline & A8 & 10 & 80 & 10 & 2.53 & 18.15 \\
\hline \multirow{7}{*}{ B } & B9 & 20 & 10 & 70 & 2.44 & 19.07 \\
\hline & $\mathrm{B} 10$ & 20 & 20 & 60 & 2.46 & 17.99 \\
\hline & B11 & 20 & 30 & 50 & 2.46 & 17.97 \\
\hline & $\mathrm{B} 12$ & 20 & 40 & 40 & 2.46 & 17.91 \\
\hline & B13 & 20 & 50 & 30 & 2.46 & 17.40 \\
\hline & B14 & 20 & 60 & 20 & 2.46 & 16.61 \\
\hline & B15 & 20 & 70 & 10 & 2.46 & 16.36 \\
\hline \multirow{6}{*}{ C } & C16 & 30 & 10 & 60 & 2.41 & 16.23 \\
\hline & $\mathrm{C} 17$ & 30 & 20 & 50 & 2.41 & 15.64 \\
\hline & C18 & 30 & 30 & 40 & 2.42 & 15.52 \\
\hline & C19 & 30 & 40 & 30 & 2.42 & 15.44 \\
\hline & $\mathrm{C} 20$ & 30 & 50 & 20 & 2.42 & 15.43 \\
\hline & $\mathrm{C} 21$ & 30 & 60 & 10 & 2.42 & 14.37 \\
\hline \multirow{5}{*}{$\mathrm{D}$} & D22 & 40 & 10 & 50 & 2.39 & 14.80 \\
\hline & D23 & 40 & 20 & 40 & 2.39 & 13.80 \\
\hline & D24 & 40 & 30 & 30 & 2.4 & 13.73 \\
\hline & D25 & 40 & 40 & 20 & 2.4 & 13.52 \\
\hline & D26 & 40 & 50 & 10 & 2.41 & 13.36 \\
\hline \multirow{4}{*}{$E$} & E27 & 50 & 10 & 40 & 2.32 & 13.61 \\
\hline & E28 & 50 & 20 & 30 & 2.32 & 13.53 \\
\hline & E29 & 50 & 30 & 20 & 2.32 & 12.82 \\
\hline & E30 & 50 & 40 & 10 & 2.34 & 13.17 \\
\hline \multirow{3}{*}{$F$} & F31 & 60 & 10 & 30 & 2.22 & 11.44 \\
\hline & F32 & 60 & 20 & 20 & 2.22 & 11.25 \\
\hline & F33 & 60 & 30 & 10 & 2.23 & 11.13 \\
\hline
\end{tabular}

\subsection{Analyzing microstructure}

Formula no. A1, C16, and F33 were selected based on its low, medium, and high bending strength, respectively. XRD pattern of them can be summarized in Tab 5. Crystallographic phase occurs in a test sample consist of Quartz, low Cristobalite and Wollastonite 2M. The composition of Wollastonite phase is $\mathrm{CaSiO}_{3}$ which can improve bending or flexural strength [16]. Due to occurring Wollastonite phase, it can be summarized that formula C16 and F33 attain high bending strength. On the other hand, non-occurrence of Wollastonite $2 \mathrm{M}$ makes formula A1 has the highest water absorption.

Table 5: Phase content of selected formulas of XRD pattern

\begin{tabular}{|c|c|c|c|c|}
\hline \multirow{2}{*}{$\begin{array}{l}\text { Formula } \\
\text { no. }\end{array}$} & \multicolumn{3}{|c|}{$\%$ Phase content } & \multirow{2}{*}{$\begin{array}{c}\text { Bending Strength } \\
(\mathrm{MPa})\end{array}$} \\
\hline & Quartz & Low Cristobalite & Wollastonite $2 \mathrm{M}$ & \\
\hline A1 & 84.75 & 15.25 & & 1.37 \\
\hline $\mathrm{C} 16$ & 55.1 & 29.98 & 14.92 & 9.86 \\
\hline F33 & 50.37 & 31.67 & 17.96 & 18.51 \\
\hline
\end{tabular}

Moreover, SEM patterns of selected formulas have been carried out as shown in Fig. 1. Fig 1(a) of formula expresses the microstructure having high porous. Meanwhile, microstructure of Fig 1(b) and 1(c) contain the glassy phase, especially Fig 1(c) also develops 
Mullite $\left(3 \mathrm{Al}_{2} \mathrm{O}_{3} 2 \mathrm{SiO}_{2}\right)$ phase (needle like shape in white circles). This can be proved that formula no.F33 has the highest bending strength.

Fig. 1 SEM micrograph of specimens containing a) formula no.A1 with 10\% wt GGC (5000X); b) formula no. C16 with $30 \mathrm{wt} \%$ GGC (5000X); c) formula no.F33 with $60 \mathrm{wt} \%$ GGC (5000X)

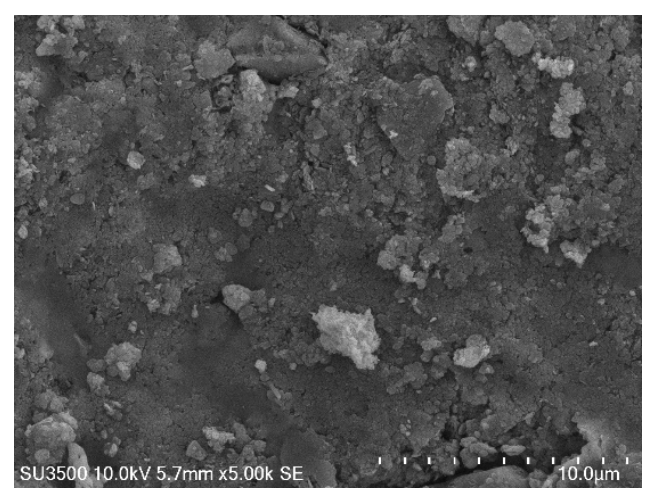

(a)

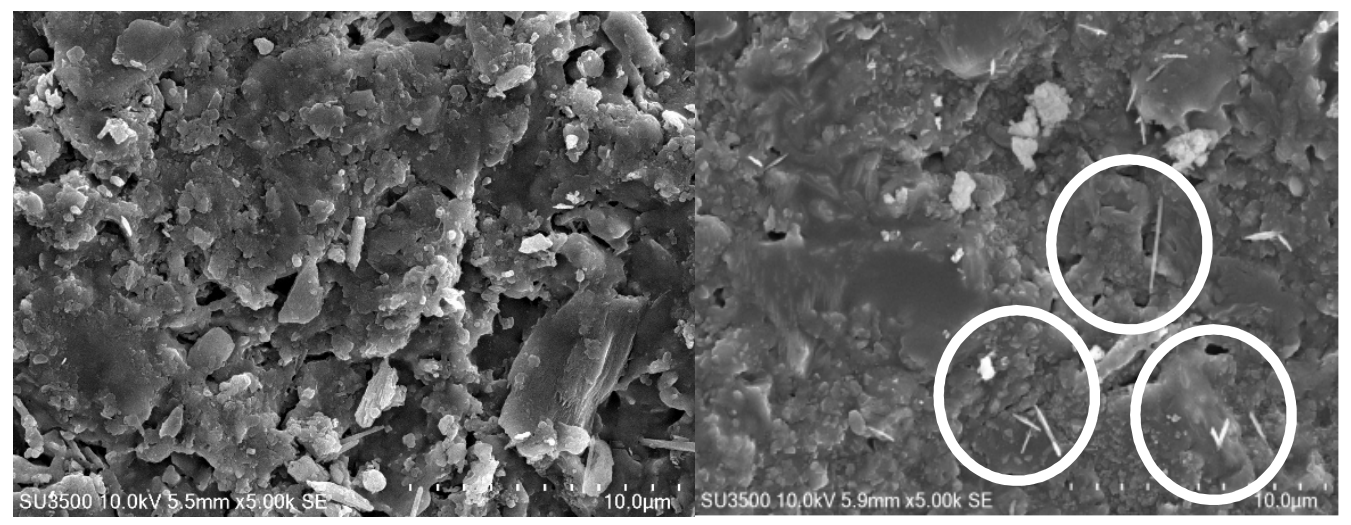

(b)

(c)

\section{Conclusions}

\subsection{Comparison physical properties with TIS 2508-2555}

Bending strength and water absorption were carried out and compared with TIS 25082555. Formulas that can achieve this standard are shown in Tab 6. They are all formulas of Group F.

Table 6: Bending strength and water absorption of formulas achieving TIS 2508-2555

\begin{tabular}{|c|c|c|c|}
\hline \multirow{2}{*}{ TIS 2508-2555 (B III) } & Bending St (MPa) & \%Water absorption \\
\cline { 2 - 4 } & F31 & >= 15 & $>\mathbf{1 0 \%}$ Each sample must not exceed 20\% \\
\cline { 2 - 4 } Formula No. & F32 & 16.57 & 11.44 \\
\cline { 2 - 4 } & F33 & 18.97 & 11.25 \\
\hline
\end{tabular}




\subsection{Comparison the best formula with fired clay products of community industry}

Formula no. F33 has the best properties for this research. Its properties have been compared with the community industry's specimens which fired at the same temperature; $950^{\circ} \mathrm{C}$. They are shown in Tab 7, which can be concluded that effect of waste glass in the test sample can enhance its bending strength.

Table 7: Comparison properties of formula no. F33 and fired clay bodies of community industry

\begin{tabular}{|c|c|c|c|c|c|}
\cline { 2 - 6 } \multicolumn{1}{c|}{} & \multicolumn{5}{c|}{ Properties } \\
\hline & $\begin{array}{c}\text { Bending } \\
\text { Strength } \\
\text { (MPa) }\end{array}$ & $\begin{array}{c}\text { \% } \\
\text { Absorption }\end{array}$ & $\begin{array}{c}\text { \%o } \\
\text { Shrinkage }\end{array}$ & $\begin{array}{c}\text { \% } \\
\text { Weight } \\
\text { Loss }\end{array}$ & $\begin{array}{c}\text { Density } \\
\text { (g/ce) }\end{array}$ \\
\hline No. F33 & 18.51 & 11.13 & 2.61 & 4.81 & 2.23 \\
\hline $\begin{array}{c}\text { Fired clay of } \\
\text { community } \\
\text { industry }\end{array}$ & 2.48 & 20.80 & 0.44 & 7.40 & 2.57 \\
\hline
\end{tabular}

\subsection{Implementation of this research work}

This research can develop wall tiles that achieve the criteria of Thai Industrial Standard (TIS 2508-2555). It can be addressed that eco-friendly wall tiles utilizing green glass cullet (GGC) is a challenge work. This can produce new products in the community ceramic industry focusing on Angthong province. Light greenish brown wall tiles were developed for responding to the needs of customers who prefer the products variety.

\subsection{Suggestions and future work}

Although this work is able to meet the research objectives. Using waste glass more than $50 \%$ weight makes the difficult work for preparing the specimens due to low plasticity of green glass cullet (GGC). Therefore, adding binder for facilitating forming work pieces should be performed. In addition, utilizing other waste materials should be investigated i.e. sediment soil from water supply treatment process, solid waste of palm oil fuel ash.

\section{Acknowledgements}

The authors would like to thank the anonymous referees for their useful suggestions. This research was funded by Thailand OHEC Talent Mobility Program 2018, Office of Higher Education Commission, Ministry of Education.

\section{References}

[1] Turner, M. Sermcheep, S. Anantasirijkiat, S. and Srisangnam, P. (2016). "Small and medium-sized enterprises in Thailand: government policy and economic development Asia Pacific," J Public Administration Vol. 38, pp. 251-269.

[2] Pollution Control Department, Ministry of Naral Resources and Environment, Thailand State of Pollution Report 2016. (2017), Available: http://www.pcd.go.th. (Accessed 3 November 2017). 
[3] Silva, R.V. Brito, de J. Lye, C.Q. and Dhir, R.K. (2017). "The role of glass waste in the production of ceramic-based products and other applications: A review," Journal of Cleaner Production. 167, pp. 346-364.

[4] Youssef, N.F. Abadir, M.F. and Shater, M.A.O. (1998). "Utilization of Soda Glass (Cullet) in the Manufacture of Wall and Floor Tiles," Journal of European Ceramic Society. Vol18(12), pp. 1721-1727.

[5] Bragança, S.R. and Bergmann, C.P. (2005). "Waste Glass in Porcelain," Material Research. Vol 8 (1), pp. 39-44.

[6] Braganca,S.R. Licenzi, Guerino, J. K. and Bergmann, C.P.(2006). "Recycling of iron foundry sand and glass waste as raw material for production of whiteware." Waste Management Research. Vol 24, pp. 60-6.

[7] Tiffo, E. Elimbi, Manga, A. J. D. and Tchamba, A. B. (2015). "Red ceramics produced from mixtures of kaolinite clay and waste glass," Brazillian Journal of Science and Technology. Vol 2(4), pp. 1-13.

[8] Luz, A.P. and Riberio, S.(2007). "Use of glass waste as a raw material in porcelain stoneware tile mixtures," Ceramic International. Vol 33, pp.761-765.

[9] Chidiac, S.E. and Federico, L.M. (2007). "Effects of waste glass additions on the properties and durability of fired clay brick," Canadian Journal of Civil Engineering. Vol 34(11), pp. 1458-1467.

[10]Loryuenyong, V. Panyachai, T. Kaewsimork, K. and Siritai, C. (2009). "Effects of recycled glass substitution on the physical and mechanical properties of clay bricks," Waste Management. Vol 29, pp. 2717-2721.

[11]Demir, I. (2009) "Reuse of waste glass in building brick production," Waste Management Research. Vol 27, pp. 572-577.

[12] Phonphuak, N. Kanyakam, S. and Chindaprasirt, P. (2016). "Utilization of waste glass to enhance physical-emechanical properties," Journal of Cleaner Production. Vol 112, pp. 3057-3062.

[13] Wiemes, L. Urivald, P. and Mymrin, V. (2016) "Incorporation of industrial wastes as raw materials in brick's formulation," Journal of Cleaner Production. Vol 142, pp.69-77.

[14]Department of Primary Industries and Mines, Ministry of Industry, DPIM Economic Review, January (2018). http://www.dpim.go.th/purchase/mainarticle?catid=137. (Accessed 1 November 2018).

[15]Information on https://sanitaryware.org/article/ball-clay

[16] Information on https://en.wikipedia.org/wiki/Wollastonite 